\title{
Stability of pillar and drive advances in hard rock mine through numerical modelling and instrumentation
}

\author{
K. K. Rao ${ }^{1, *}$, B. S. Choudhary ${ }^{2, *}$ and G. D. Raju ${ }^{3}$ \\ ${ }^{1}$ Tummalapalle Mine, Uranium Corporation of India Ltd, Jharkhand 832 102, India \\ ${ }^{2}$ Department of Mining Engineering, Indian Institute of Technology, Dhanbad 826 004, India \\ ${ }^{3}$ National Institute of Rock Mechanics, Kolar Gold Fields 563 122, India
}

Rock support systems are used to maintain the stability of underground openings and reinforce disturbed rock masses after creating an excavation. This study, in turn, will help in the selection of an appropriate number of blasts in a drive, from where the support system is required to stop mitigation of the stressdeformation conditions around it. Here, two models have been built and simulated using the RS2D programme, i.e. first to optimize the pillar and gallery size for maximum safety and extraction ratio and second is evaluation by numerical modelling and validation with rock mechanics instruments to study on mining-induced stresses, factor of safety, and displacement around the drive with no rock support system for every blast advance. The interpretation of instrumentation data collected shows that drive stability suffers significantly, with no rock support after third blast in the second model and necessity of proper rock support system is confirmed and validated.

Keywords: Factor of safety, instrumentation, mine development, mining-induced stresses, numerical modelling.

UNDERGROUND excavations can stand stable for a long time without support if they are driven in a rock mass of good quality. On the other hand, an adequate support system is inevitably required if these excavations have been created in a rock mass of poor geological conditions (e.g. a heavily jointed rock mass). Consequently, a support system must then be installed to secure excavations against the potential failure of a disturbed rock mass and provide safe access for persons and machinery during their life span (e.g. service life) with minimum $\operatorname{costs}^{1,2}$.

The prominent function of a rock support system in underground mines is to conserve the inherent strength of the rock mass to support itself after it has been disturbed by excavation activity. It also helps to transfer the weight

\footnotetext{
*For correspondence. (e-mail: kkrao@uraniumcorp.in;
}

bhanwarschoudhary@iitism.ac.in) from a loose/disturbed rock mass to a solid, intact and fresh rock mass. Therefore, it acts as a reinforcement element ${ }^{2}$. Sometimes the design of a rock support system is performed prior to an excavation. However, this design is still site-specific (e.g. there is no single/unique design of rock support system that could be applied for all mines).

A rock support system may be selected using empirical (e.g. classifications), analytical (e.g. calculations) and/or numerical methods. The empirical methods depend on the statistical analysis of underground observations and the rock mass classification system; which are used in the initial stage of the project when little or no detailed information is available. The most common empirical methods used in underground mines are Lang's method, the Farmer and Shelton method, Rock Quality Designation (RQD) and the Q-support chart. However, these methods have many limitations, such as they do not account for the effect of the shape of the opening, distribution of mining-induced stresses around the opening, in situ stress regimes (e.g. magnitude and orientations), rock mass deformations and the location and extent of failure zones $^{3-10}$.

For safe extraction of ore, all underground mining methods resort to use of pillars either temporary or permanent. As the strength of the pillars cannot be measured directly, it is estimated indirectly from the back analysis. This approach of back calculation has led to the development of empirical pillar strength formulae ${ }^{11}$. The coal mine pillar design is very common by using these empirical formulae as most of the experiences are from coal mines. With the experiences from the hard rock case studies, different empirical strength formulae for hard rock pillars have also been developed. The empirical formulae developed by various authors for hard rock pillar strength are presented in Table 1.

For the present study, it was felt that the equation proposed by Hedley and Grant ${ }^{12}$ is most relevant as the experiences are from uranium mines and the same is used to estimate the pillar strength.

The analytical methods are only useful in the preliminary design phase. They use regression analysis (e.g. estimate 
Table 1. Empirical strength formula for hard-rock pillars ${ }^{11}$

\begin{tabular}{lll}
\hline Author & Pillar strength, $p(\mathrm{MPa})$ & UCS $(\mathrm{MPa})$ \\
\hline Hedley and Grant & & \\
Kimmelmann et al. $^{18}$ & $133\left(\mathrm{~W}^{0.5} / \mathrm{H}^{0.75}\right)$ & 230 \\
Krauland and Soder $^{19}$ & $65\left(\mathrm{~W}^{0.46} / \mathrm{H}^{0.66}\right)$ & 94 \\
Potvin et al. $^{20}$ & $35.4(0.778+0.222(\mathrm{~W} / \mathrm{H}))$ & 100 \\
Sjoberg $^{21}$ & $0.42 \sigma_{\mathrm{c}}(\mathrm{W} / \mathrm{H})$ & - \\
Lunder and Pakalnis $^{22}$ & $74(0.778+0.222(\mathrm{~W} / \mathrm{H}))$ & 240 \\
\hline
\end{tabular}

rock mass strength based on the support charts) to design/select appropriate support system. However, they are not efficient enough to assess complex mine geometry in deep underground mines (e.g. as mining depth increases, highly stressed ground conditions exist and lead to rockbursts and seismicity occurrences) $)^{3-13}$.

The third method, numerical modelling, is the most acceptable tool in underground mines (e.g. it can be employed for any ground conditions). This method has the capability to simulate very complex mine geometry and provide a complete solution (e.g. static and dynamic) for the rock mass behaviour at any depth below the surface $^{14-16}$.

Usually, the design of a rock support system is selected based on field observations, past experience of similar cases and precedent practice gained during trial excavations and early mining stages in certain areas. But these days, available numerical modelling software are used for designing the support system in development or stoping of underground mines.

\section{Objectives}

The objectives of this study are

- To optimize the pillar and gallery size for maximum safety and extraction ratio below 100-200 m depth and to examine the effect of support on the performance stability of underground drives that exist in hard rock mines, in terms of mining-induced stressdeformation, the factor of safety near the face and its sides around the face/rock mass surrounding the drive (model-I).

- To evaluate the stability of the rooms and gallery/ drive through numerical modelling and validation through rock mechanics instrumentation with interpretation to improve the maximum underground rate of advance without support (model-II).

To meet these objectives, it is necessary to mention that the mine produces $60 \%$ ore by development and requires $85 \%$ development by excavation as per the mining method. To enhance the advance rates of the mine, which is having very hard rock such as uniaxial compressive strength (UCS) in the range 350-400 $\mathrm{MPa}$, a mine specific burn cut was designed.

\section{Geo-mining conditions and mining details}

This study is based on the underground uranium deposit situated in the Kadapa district of Andhra Pradesh. The mine is planned to produce 3000 TPD and also proposed to have an expansion for 1500 TPD. The mineralization occurs within Vempalle carbonate rock, which is a strata bound formation. It is basically a dolomitic limestone ('dolostone'), along with stromatolites. The ore body is uniform in its thickness and trend, with an average dip of $15^{\circ}$ due $\mathrm{N} 22^{\circ} \mathrm{E}$. The extent of the ore body is $5.6 \mathrm{~km}$ along the strike and $1 \mathrm{~km}$ along dip, with overburden depth ranging from $15 \mathrm{~m}$ to $275 \mathrm{~m}$. The ore body consists of two bands: hangwall lode (average width $3.2 \mathrm{~m}$ ) and footwall lode (average width $2.5 \mathrm{~m}$ ), separated by 1.5 $3 \mathrm{~m}$ thick lean zone. The depth of the present mine workings is below $100 \mathrm{~m}$. The weathering zone (weathering grade W2) extends for 40-50 m below the surface. Three declines, of $5 \mathrm{~m}$ in width and $3 \mathrm{~m}$ in height, along an apparent dip of $9^{\circ}$ due NE, are driven $15 \mathrm{~m}$ apart to work the two lodes at different levels. From the east and central declines, level galleries called advance strike drives (ASDs), are driven at $38.5 \mathrm{~m}$ interval (vertical interval is roughly $10 \mathrm{~m}$ ).

The mine development operations are done by deploying various trackless diesel-driven equipment. The major equipment are Load Haul Dumps (LHDs) for loading of the blasted muck into dumpers, Low Profile Dump Truck (LPDTs) to transport the same to the surface or grizzly, face drilling is done by Jumbo Drills, Rock bolter is deployed for drilling support holes and installing rock bolts to support the immediate roof faster and material transportation is carried out with help of MPV (multi-purpose vehicle). As far as drilling equipment for drive is concerned, Jack hammer and single boomed electrohydraulic Jumbo drills (low profile and extra low-profile) are used for linear excavation. The parallel and reamers holes can be drilled easily, and rate of penetration is also quite faster in case of low profile and extra low profile and single-boomed electro-hydraulic jumbo drills. The best pull or rate of advance is found in extra low-profile equipment. 


\section{RESEARCH ARTICLES}

(a)

(b)

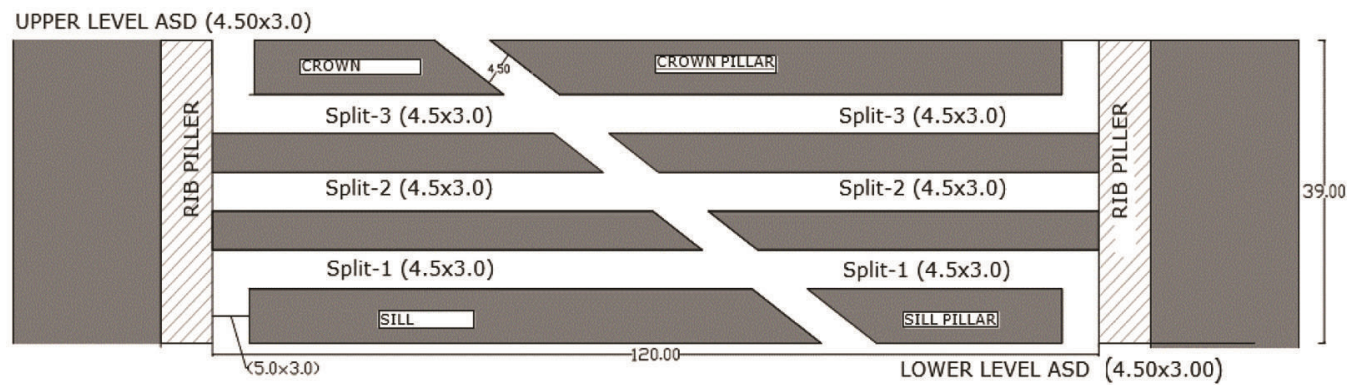

(c) UPPER LEVEL ASD $(4.50 \times 3.0)$

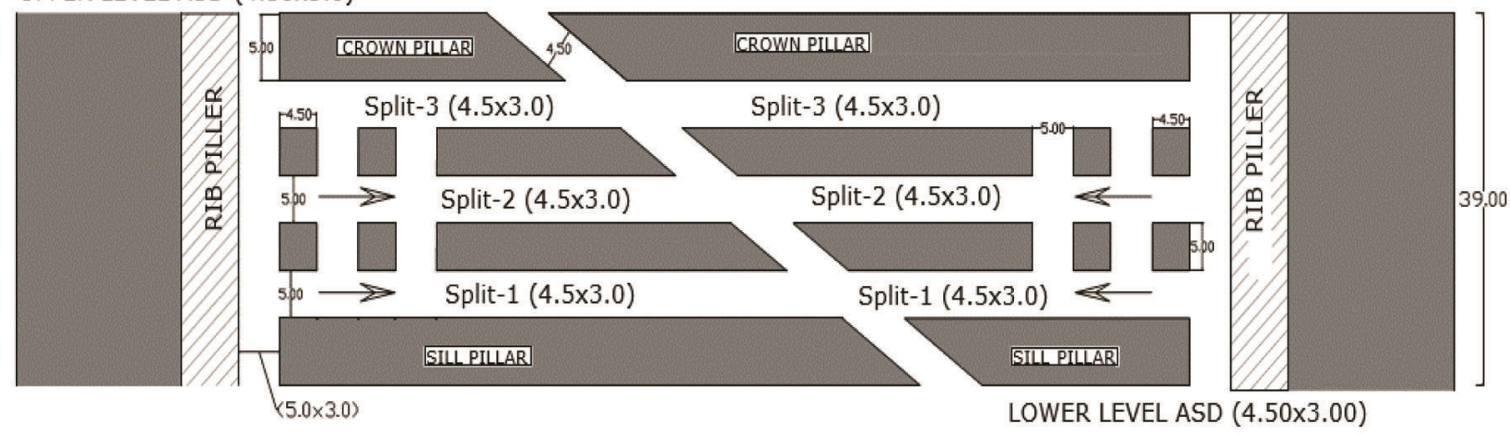

(d)

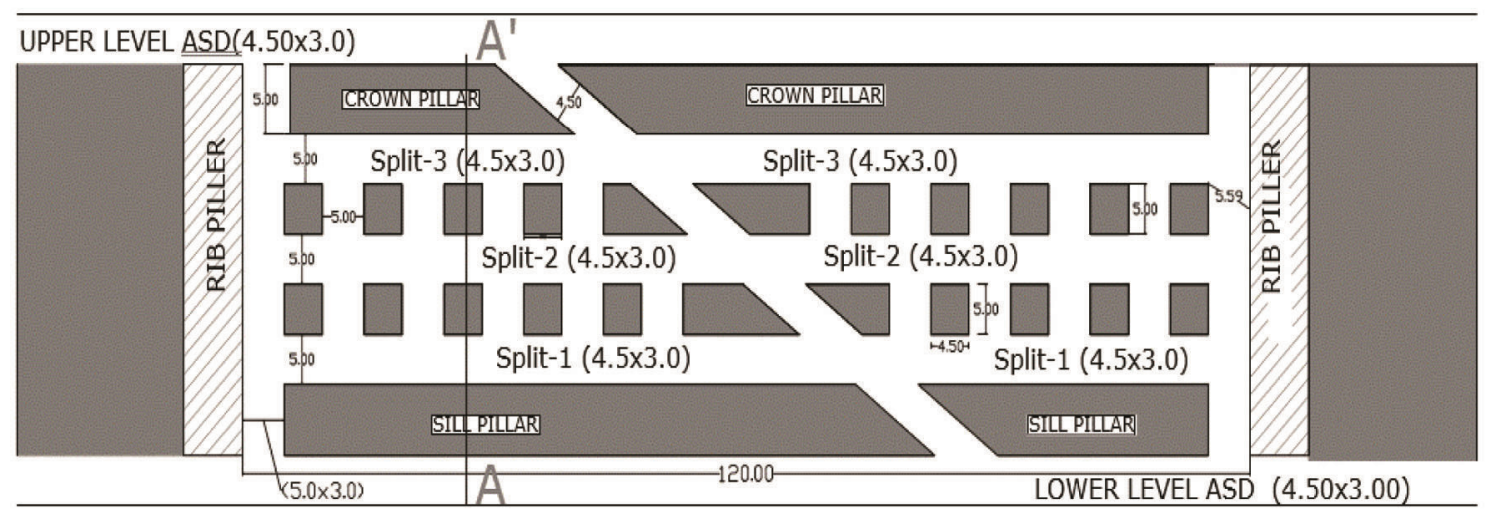

Figure 1. $\boldsymbol{a}$, A panel developed with $4.5 \mathrm{~m} \times 3.0 \mathrm{~m}$ ramp which is connected between two levels. $\boldsymbol{b}$, Development of stope drive up to rib pillar (split-3). $\boldsymbol{c}$, Formation of pillar by connecting three numbers of splits to each other. $\boldsymbol{d}$, Left out pillars after footwall stoping.

Details of extraction of footwall lode according to the current practice of room and pillar mining are described in a sequence of operations and also shown in Figure $1 a-d$ :
- A stope block of $120 \mathrm{~m}$ along the strike and $38.5 \mathrm{~m}$ along the dip is identified between two advance strike drives (ASDs) (upper level and lower level). 


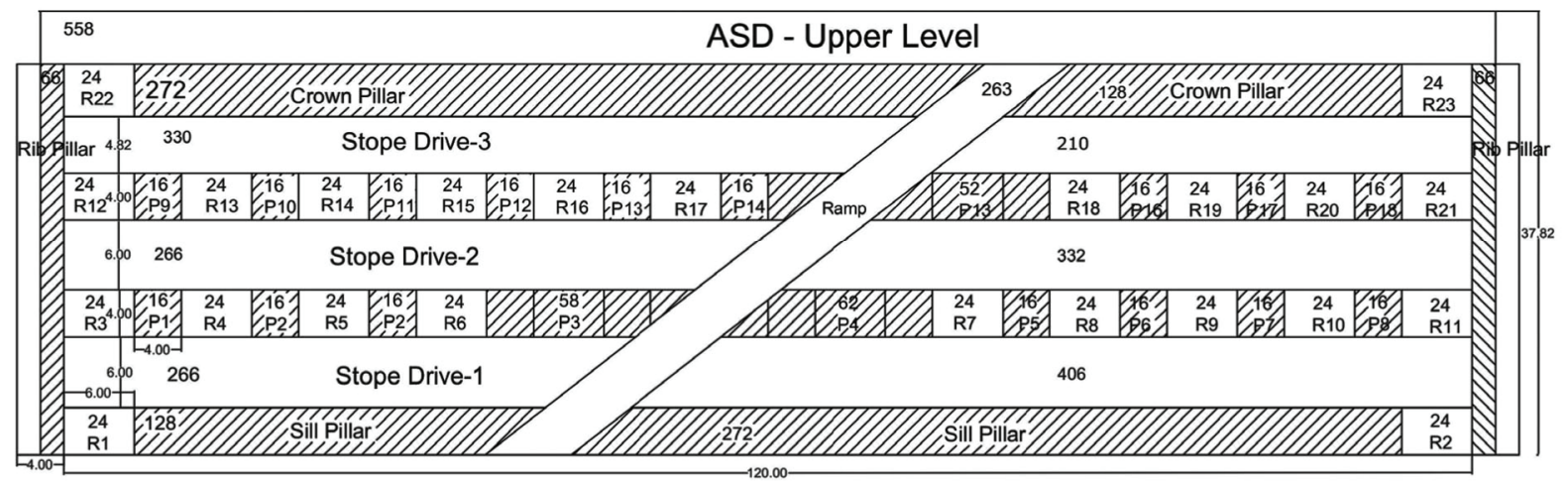

Figure 2. Schematic diagram - ore recovery and pillar loss in footwall lode.

Table 2. Calculations - linear development, ore recovery and pillar loss in footwall lode

\begin{tabular}{|c|c|c|c|c|c|}
\hline \multicolumn{3}{|c|}{ Percentage of linear advance in a panel } & \multicolumn{3}{|c|}{ Pillar loss area } \\
\hline Excavation & Linear development (m) & $(\%)$ & Pillar description & Area $\left(\mathrm{m}^{2}\right)$ & Area $(\%)$ \\
\hline ASD upper level/lower level & 240 & $31 \%$ & Sill and crown pillars & 800 & $17 \%$ \\
\hline Ramp & 65 & $9 \%$ & Remnant pillars & 440 & $10 \%$ \\
\hline Stope drives & 345 & $45 \%$ & Rib pillars & 132 & $3 \%$ \\
\hline Rooms (dip-rise connections) & 115 & $15 \%$ & Sub-total & 1372 & $30 \%$ \\
\hline Sub-total & 765 & $100 \%$ & & & \\
\hline
\end{tabular}

Total linear development in a panel $=765 \mathrm{~m}$ area is equivalent to $70 \%$ of total recoverable area.

- A ramp is driven between the bottom and top ASDs along an apparent dip of $9^{\circ}$.

- From the ramp on either side, drives are made parallel to the ASDs (called 'stope drives'). These drives would initially be of $4.5 \mathrm{~m}$ width, fully supported and then would be widened to $6 \mathrm{~m}$ by taking stripping $1 \mathrm{~m}$ all along the dip side. There can be three stope drives (1, 2 and 3$)$ in each stope, the dip-most stope drive is driven first.

- Sequence of reduction of pillars in footwall lode is as below: (i) Widening of stope drives: The widening of stope drives up to a maximum of $6.0 \mathrm{~m}$ width while ensuring a minimum of $4.0 \mathrm{~m}$ thick pillar between adjacent stope drives/ASDs. (ii) Formation of rooms and remnant pillars: The interconnection of stope drives/ASDs to form rooms of maximum $6.0 \mathrm{~m}$ width (measured from one pillar to another pillar perpendicular to the centerline of a stope drives/ramp) leaving $4.0 \mathrm{~m} \times 4.0 \mathrm{~m}$ remnant pillar. (iii) These series of diprise connections is made in a regular pattern forming rooms, by leaving rectangular pillars as explained above, is done in a retreat manner from rib pillar towards ramp.

Figure 2 represents the shape and sizes of rooms and pillars in an ideal case for stoping panels in footwall lode.

Table 2 represents the calculation for extent of linear development required including rooms and pillars and in an ideal case for stoping panels in footwall lode.
The recoverable reserve shall be considered as $65 \%$ for footwall lode for all estimation. The table also indicates that $70 \%$ of production comes from linear development. Faster the development, more is the rate of production. Hence the study is being carried out to improve the rate of advance.

\section{Numerical modelling results}

With a view to ascertain the stability of remnant pillar, crown pillar, rib and sill pillars, a 2-dimensional numerical modelling was performed. For this purpose, two different models were created. The first model (model-I) to ascertains the stability of the remnant rib pillars and drive of the gallery. The model geometry for this is shown in Figure 3. The second model (model-II) studies the behaviour of the drive/stope drive in a gallery. It can be observed from Figure 3, that the actual lithology up to the surface is considered in the model. The maximum depth of mining $(200 \mathrm{~m})$ was also considered for the worst-case simulation.

\section{Model-I}

The model as shown in Figure 3 is created to study the stability of the stope drives, rooms, remnant and rib pillars of the proposed panel. It also aimed to examine the stability of the rib and remnant pillar when the footwall 


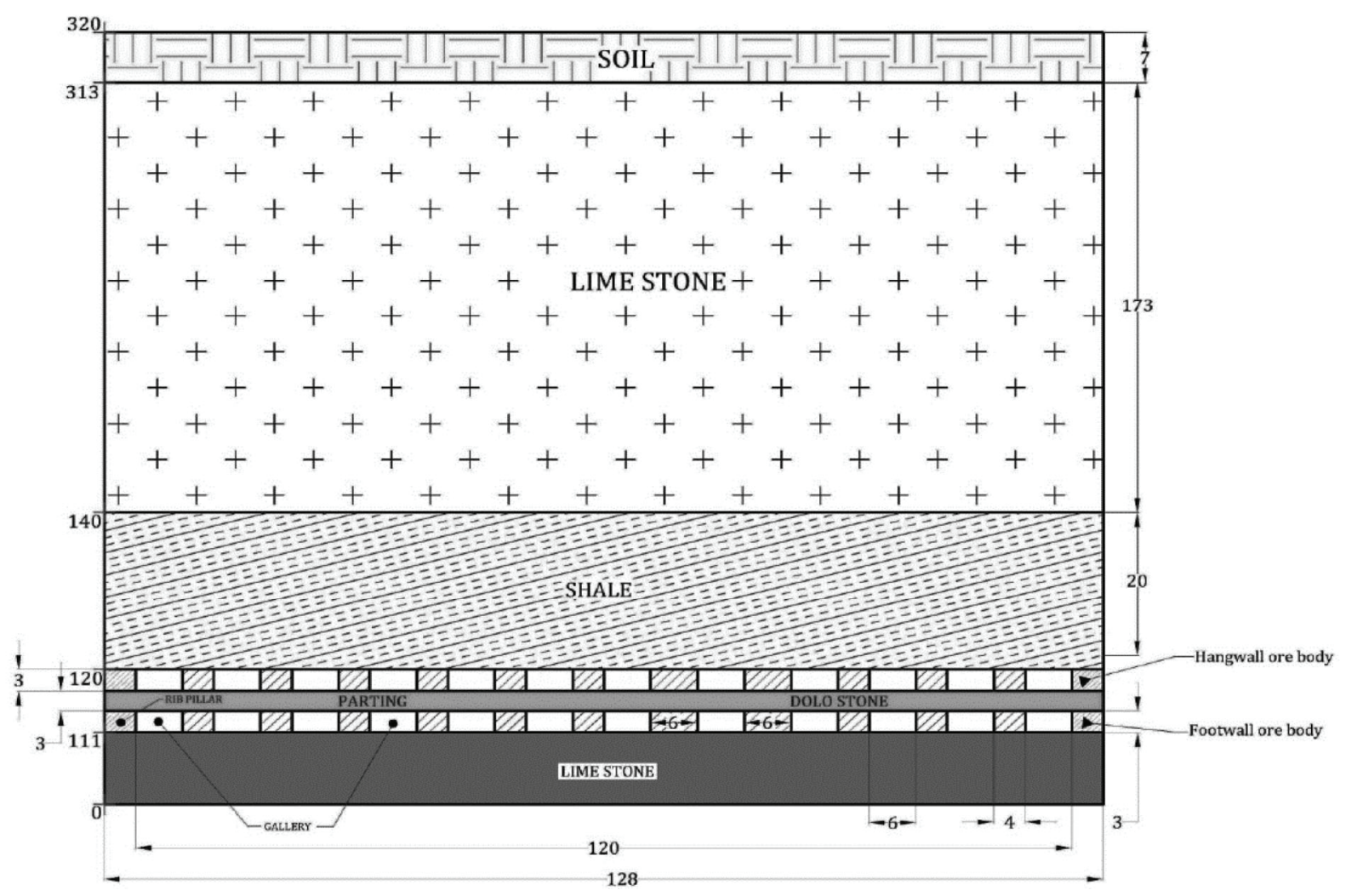

Figure 3. Model geometry for model-I.

Table 3. Material properties used in the present model (tested at NIRM)

\begin{tabular}{lccc}
\hline Property & Dolostone & Shale & Limestone \\
\hline Uniaxial compressive strength of rock (MPa) & 260.50 & 181.07 & 377 \\
Cohesion (MPa) & 15.52 & 4.63 & 9.73 \\
Friction angle (degree) & 35 & 38 & 29 \\
Tensile strength (MPa) & 24.29 & 12.2 & 10.73 \\
Poisson's ratio & 0.24 & 0.21 & 0.3 \\
Young's modulus (GPa) & 97 & 57 & 95 \\
Density $\left(\mathrm{kg} / \mathrm{m}^{3}\right)$ & 2780.90 & 2718.56 & 2820.50 \\
\hline
\end{tabular}

mining is done. The mining-induced stress and the FOS values over the pillars due to the footwall mining is examined. The stability of the pillars with and without supports is also examined. All the material properties for the analysis are obtained from the laboratory testing of the relevant rock samples collected from the mine and given in Table 3. For the purpose of in situ stress conditions, vertical loading was calculated for vertical stresses and the horizontal stresses were taken as twice the vertical stresses. The Finite element model with various materials and the pillars was formed for the analysis.

The model was simulated under mining method in footwall lode mining along with drives, stope drives and rooms. Results of the analysis were obtained in the form of stresses and strength factor (FOS) around the excavations.
The mining-induced stresses and the strength factor around remnant and rib pillars (sizes of $4 \mathrm{~m} \times 4 \mathrm{~m}$ and $4 \mathrm{~m}$ respectively, were selected considering the factor of safety and optimum recovery of the ore) after footwall lode mining is shown are Figure $4 a$ and $b$ respectively. For the convenience of the visibility, part of the model containing the representative rib pillar and remnant pillar is zoomed to show the condition of the rib and remnant pillars.

It can be observed from the Figure $4 a$, that the maximum stress induced due to the footwall lode mining is of the order of $29.37 \mathrm{MPa}$ and is concentrated mostly around the corners of the rib and remnant pillars. The stress concentration at centre of the pillars and the roof of the gallery was of the order of $12 \mathrm{MPa}$ only. The FOS values around the excavation are shown in Figure $4 \mathrm{~b}$. It 

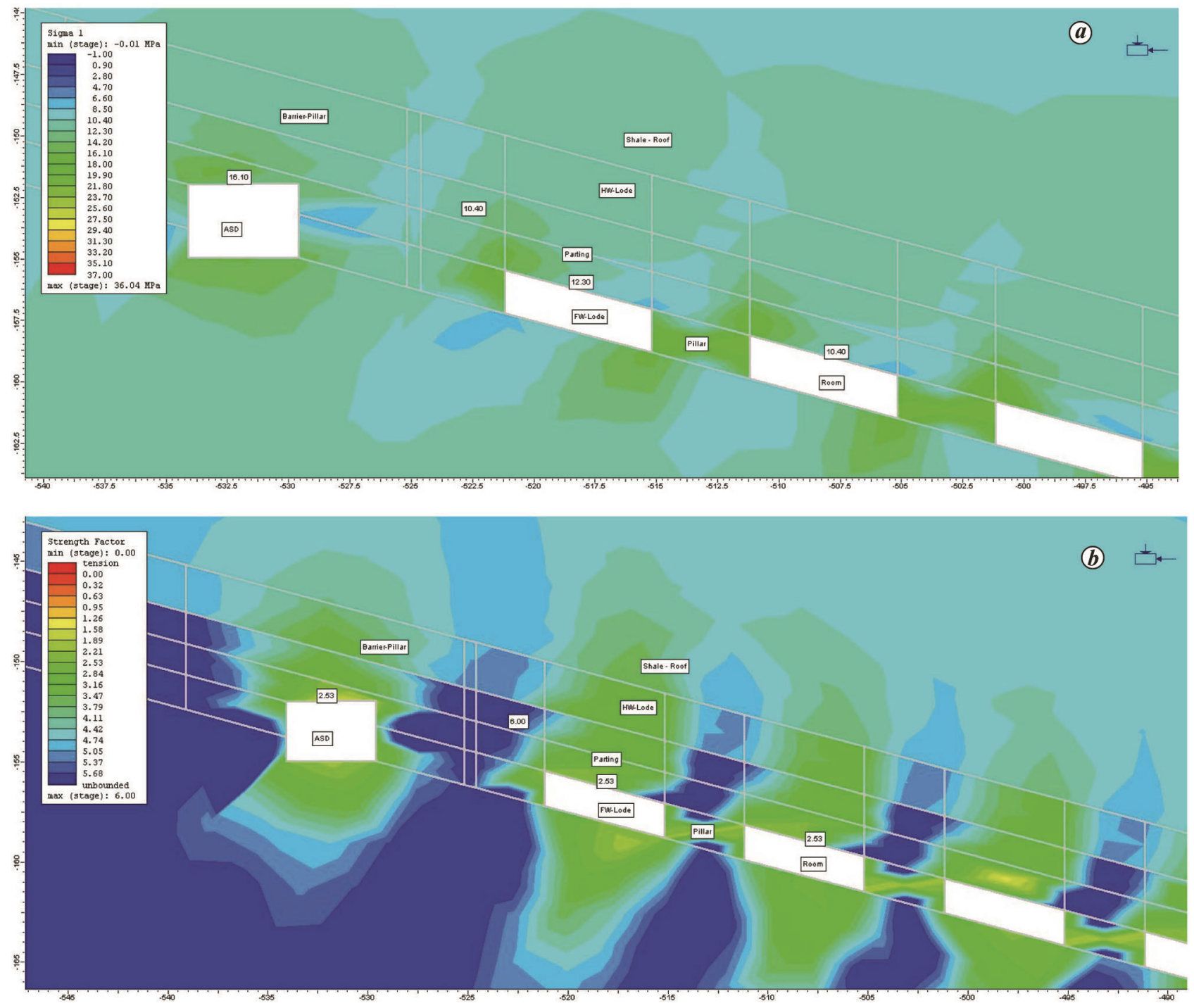

Figure 4. $\boldsymbol{a}$, Mining induced stresses in section of sub-panel around the rib and remnant pillars after forward lode mining. $\boldsymbol{b}$, FOS values in section of sub-panel around the rib and remnant pillars after footwall lode mining.

can be observed that the rib and remnant pillars show a high FOS of around 5.68. The roof of the gallery has FOS of around 2.21 .

\section{Results}

- It was observed that the results of numerical modelling results also confirm the stability of the pillar sizes of $4 \mathrm{~m} \times 4 \mathrm{~m}$ with $6.0 \mathrm{~m}$ wide gallery/drive/stope drive with FOS values varying from 4 to 6 over the rib and remnant pillars.

- The unsupported stand-up time of already excavated stope drives of $4.5 \mathrm{~m}$ wide with the full column cement grouted rock bolts as permanent support and considering the life of rock bolts the stand-up time of the supported galleries/drive/stope drives of $4.5 \mathrm{~m}$ wide can be more than 10 years. This can also be evi- denced from the field as no incidence of any deterioration of these galleries till date. The gallery will have no stability issues unless there is any stress alteration due to surrounding mining activity. Hence $4.5 \mathrm{~m}$ width $\times 3.0 \mathrm{~m}$ height galleries/stope drives may be optimized dimensions for purpose of development.

- In addition, the pillars formed due to these galleries also offer the additional support to galleries, as these pillars themselves have high FOS according to numerical modelling results.

- It is highly recommended that the excavated stope drives of $4.5 \mathrm{~m}$ wide, which are standing for long, should be instrumented for monitoring the stability of the drive/stope drive effectively.

To validate the above recommendation and to evaluate the stability of stope drive/drive in the gallery, model-II was designed for numerical modelling, which was 

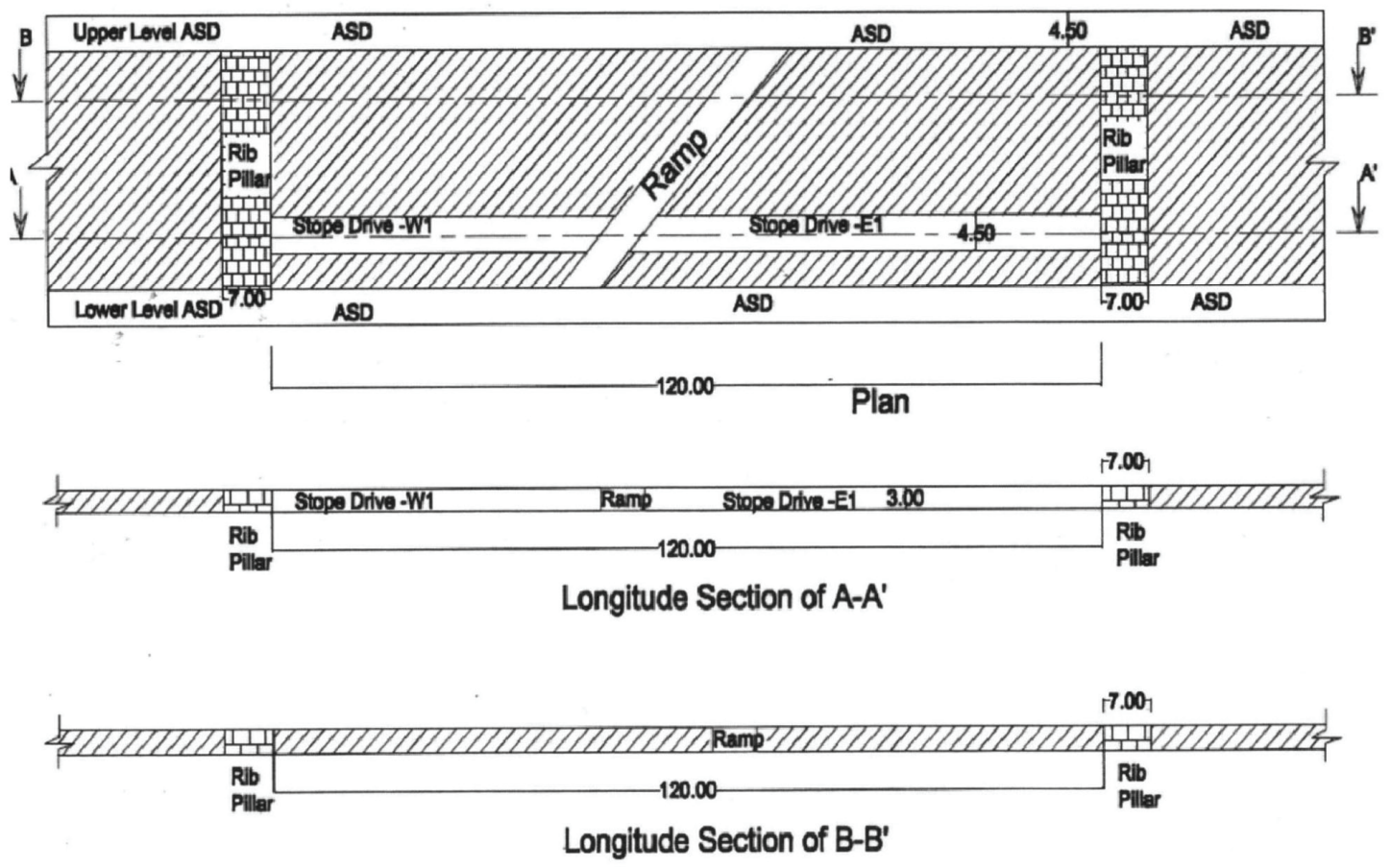

Figure 5. Plan and section of the panel (model-II) considered for numerical modelling ${ }^{20}$.

discussed by Rao et al. ${ }^{17}$. In the present paper, model-I explains the mining-induced stress parameters and factor of safety of a panel with the existing mining method (room and pillar), where systematic support rules approved by DGMS were practiced (i.e. full column bolts/ supporting in every blast). The model-I gave results of the stabilized dimensions of the gallery/drive and the various pillars with full column bolts. The model-II described in Rao et al. ${ }^{17}$ is trial to increase the rate of advance with minimum bolting operation requirement. The maximum mining-induced stress observed in model-II for the gallery of drive is of the order of $34 \mathrm{MPa}$ at the fourth advance of blast. It is observed that, results of model-II on higher side and hence rock mechanics instrumentation study was carried out underground for the stope drives/level drives. The results of strata behaviour from the data obtained with the instruments were analysed.

\section{Model-II for stable and faster drivages}

In order to ascertain the stability of stope drive and the minimum advance before installing rock bolt support system, a 2-dimensional numerical modelling was performed. For this purpose, a longitudinal section of the panel as shown in Figure $1 d$ is simulated as Figure 5. This modelling analysis presents the results of the simulation under various stages of stope drive advance and including the blasting effect on the face surroundings in Figure 6. Actual lithology up to the surface is considered in the model.

\section{Instrumentation in trial drive/stope drive}

Trial advance strike drive was developed between the upper level ASD and lower level ASD and stope drive-west 1 and stope drive-east 1 to ascertain and understand the actual behaviour of strata for its stability. For monitoring the strata behaviour during the development operations, the trail stope panel was instrumented with various instruments as shown in Table 4. As observed from Table 4 that 4 nos of stress cells (S-1 to S-4), 1 no of load cell (L-1) and 5 nos of extensometer (EX-1 to EX-5) were installed to monitor the various geotechnical parameters in trial panel.

All the above instruments were installed after the formation of level drives and ramp-up up to $5 \mathrm{~m}$ in bye end of the panel. Subsequently, the instruments were mentioned after the fully bolted ramp up is ready for the first stope drive blast. The data was analysed to understand the strata behaviour at various stages of development and rock bolt operations up to after the fourth blast from ramp up face. The results of the data thus analysed were also compared with the results of numerical modelling.

\section{Instrumentation results}

The results of various instruments such as stress cells, load cells and extensometers are presented in the following sections.

Stress cells: The data obtained from the stress cells installed at the either side of the stope drive locations are 


\section{RESEARCH ARTICLES}
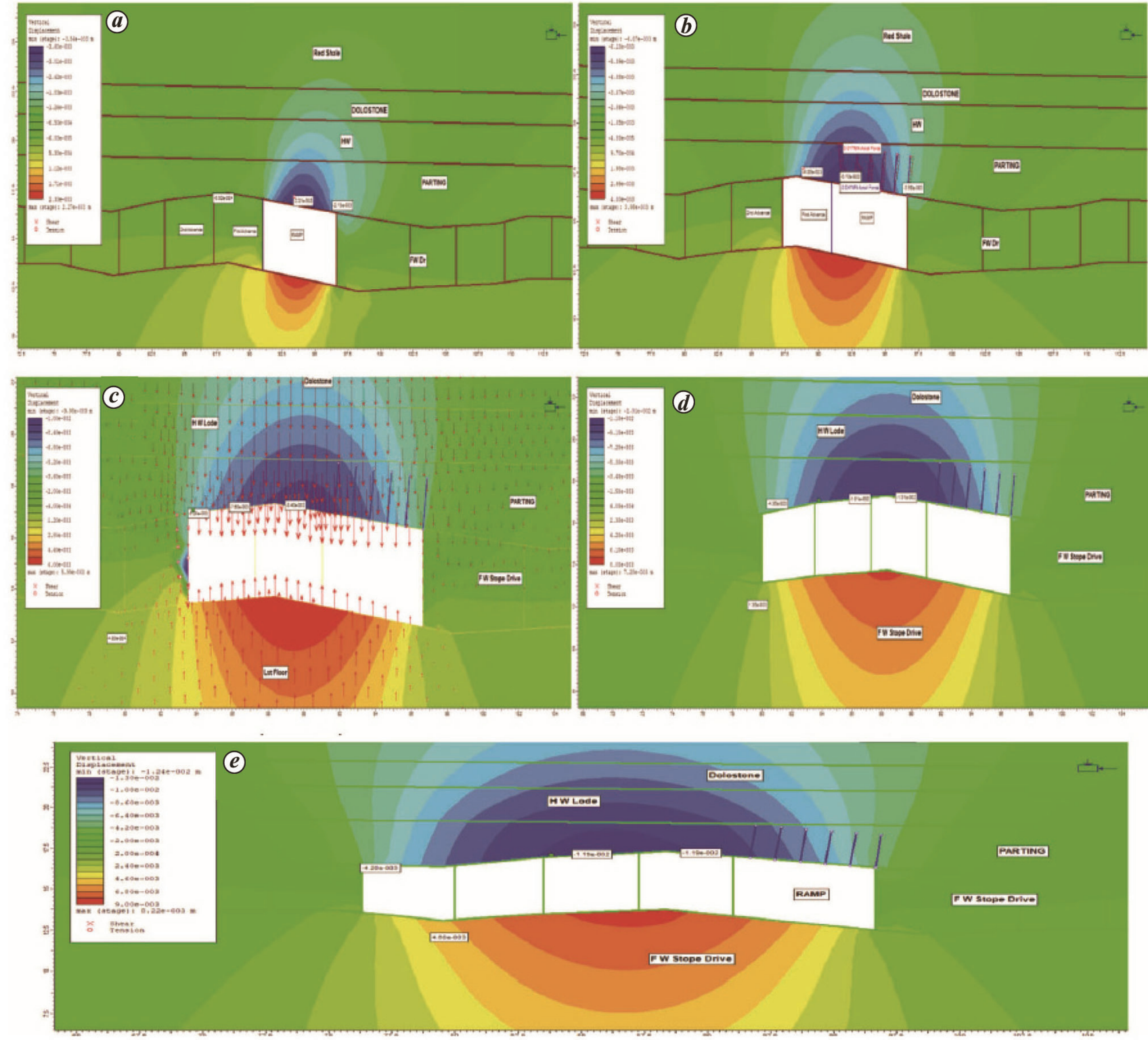

Figure 6. Deformation simulations. $\boldsymbol{a}$, Displacement in ramp only; $\boldsymbol{b}$, Displacement in ramp + one advance (blast-1); $\boldsymbol{c}$, Displacement in ramp + two advances (blast-2); $\boldsymbol{d}$, Displacement in ramp + three advances (blast-3); $\boldsymbol{e}$, Displacement in ramp + four advances (blast-4) ${ }^{17}$.

Table 4. Instrument details installed in trial panel of size $120 \mathrm{~m}$ length $\times 40 \mathrm{~m}$ width for model-II

\begin{tabular}{lllc}
\hline Inst-ID & \multicolumn{1}{c}{ Instruments } & \multicolumn{1}{c}{ Location } & Quantity \\
\hline EX-1 & Multi point bore hole & Ramp U/P-1 & 1 \\
EX-2 & extensometers & Stope drive East-1 & 1 \\
EX-3 & (MPBX) & Stope drive East-2 & 1 \\
EX-4 & & Stope drive East-3 & 1 \\
EX-5 & & Stope drive East-4 & 1 \\
S-1 & & Stope drive East-1 (side wall) & 1 \\
S-2 & & Stope drive East-2 (side wall) & 1 \\
S-3 & Stress cells/meters & Stope drive East-3 (side wall) & 1 \\
S-4 & & Stope drive East-4 (side wall) & 1 \\
L-1 & Anchor load cells & Stope drive East-1 (centre of roof) & 1 \\
\hline
\end{tabular}


Table 5. Results of instrumentations for model-II

\begin{tabular}{|c|c|c|c|c|c|}
\hline \multicolumn{6}{|c|}{ Results of stress cell measurements } \\
\hline & $\mathrm{S} / \mathrm{D}(\mathrm{E}-1)$ & $\mathrm{S} / \mathrm{D}(\mathrm{E}-2)$ & $\mathrm{S} / \mathrm{D}(\mathrm{E}-3)$ & S/D (E-4) & Remarks \\
\hline Date & $\mathrm{S} 1$ & $\mathrm{~S} 2$ & $\mathrm{~S} 3$ & $\mathrm{~S} 4$ & \\
\hline 6 July 2018 & 27.03 & 0.00 & 0.00 & 0.00 & First blast after ramp up \\
\hline 6 July 2018 & 27.82 & 29.02 & 0.00 & 0.00 & Second blast after ramp up \\
\hline 6 July 2018 & 27.96 & 29.43 & 30.06 & 0.00 & Third blast after ramp up \\
\hline 6 July 2018 & 27.53 & 29.54 & 30.36 & 32.10 & Fourth blast after ramp up \\
\hline \multicolumn{6}{|c|}{$\begin{array}{l}\text { Results of load cell measurements } \\
\qquad \text { S/D(E-1) (on roof bolt) }\end{array}$} \\
\hline Date & & & $\mathrm{L} 1$ & & \\
\hline 6 July 2018 & & & 4.40 & & First blast after ramp up \\
\hline 6 July 2018 & & & 4.61 & & Second blast after ramp up \\
\hline 6 July 2018 & & & 5.26 & & Third blast after ramp up \\
\hline 6 July 2018 & & & 6.41 & & Fourth blast after ramp up \\
\hline
\end{tabular}

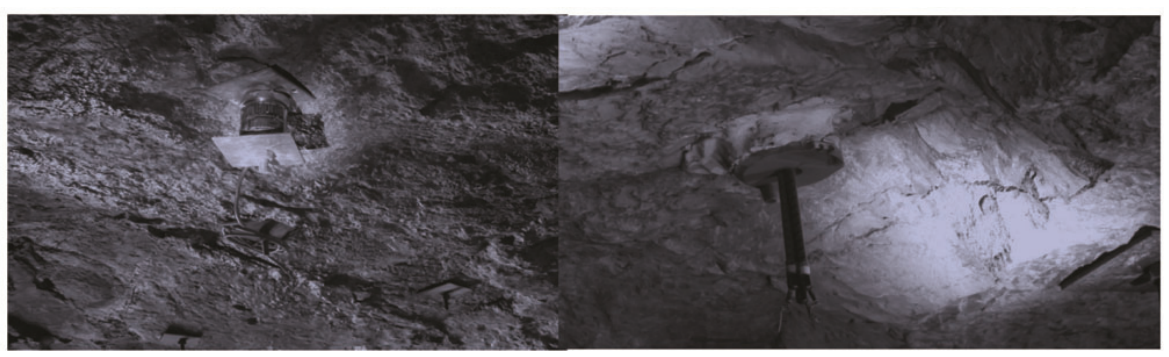

Figure 7. Load cell and extensometer installation images at underground.

presented in Table 5. With each blast from ramp up towards stope drive, readings were taken from the read-out unit. It can be observed from Table 4 that the maximum stress change measured for instrument ID S4 is of the order of $32 \mathrm{MPa}$. The stress change in other locations, i.e. S1, S2 and S3 (27, 29 and $30 \mathrm{MPa}$ respectively) is of the order of less than $30 \mathrm{MPa}$.

Load cells: The data obtained from the load cells installed (Figure 7) on the rock bolts at one location, i.e. bolt of the ramp up are presented in Table 5. With each blast from ramp up towards stope drive, readings were taken from the read-out unit. It can be observed from the table that the maximum load on the rock bolts measured for instrument ID L1 is of the order of $6.4 \mathrm{t}$ in fourth blast.

Deformation: The deformation data were obtained from the tell-tale extensometers which was installed in the centre of the roof and exposed with each blast as the face progresses. It means five instruments were needed for the experiment. Precautions were taken to protect the instruments from blast damage by putting the instrument inside the box made of $8 \mathrm{~mm}$ thickness MS plate, which is fixed externally between both the side walls of drivage. It shows that the deformation is less than $4.5 \mathrm{~mm}$ in any of the locations, except $8.2 \mathrm{~mm}$ at the fourth blast.

\section{Rock bolt anchorage testing}

The data obtained from the anchorage testing machine are recorded for $25 \%$ bolts in bound-paged book after every advance of blast. The bolts installed at ramp were tested for maximum load taking capacity up to 10-12 tonnes and it shows good result. The destructive test was done on $1 \%$ bolt, which failed in 11 tonnes, which is good enough. After the numerical modelling and instrumentation, it was found that during the fourth round of drill, there is a need of supporting the drive. Therefore, it is necessary to look for faster drilling options, which could drill and support at face.

\section{Conclusions}

(1) The model-I confirms the stability of the pillar sizes of $4 \mathrm{~m} \times 4 \mathrm{~m}$ with $6.0 \mathrm{~m}$ wide gallery/drive/stope drive with FOS values varying from 4 to 6 over the rib and remnant pillars.

(2) The data obtained from various instruments in model-II are recorded and regular analysis was done with no support system for every advance of blast. The analysis of the data obtained from various instruments (load cells, tell-tale extensometers and strain points) reveals there is negligible/no change in load on to the rock bolts, roof deformation and 
strain respectively, and is similar with prediction in the numerical modelling.

(3) It was observed that the deformations in the roof were progressively increasing particularly at the centre of the roof for every advance and it reached more than $10 \mathrm{~mm}$ after the third advance according to numerical modelling but on instrumentation its results are in agreement with prediction, i.e. $8.4 \mathrm{~mm}$ deformation. At the same time the formation of stress relaxation arch in the roof was observed which will lead to roof failure in the absence of roof reinforcement in the form of rock bolts. The maximum mining induced stress observed was of the order of $34.0 \mathrm{MPa}$, according to numerical modelling but on instrumentation, the results are in good agreement with prediction, i.e. $32 \mathrm{MPa}$.

(4) In the model-2, the roof bolts fixed at the ramp from where the stope drive progressed, are loaded moderately to their $64 \%$ capacity only, even after the third blast. The anchorage testing results show that the rock bolts at the ramp are still able take load up to 10-12 tonnes after the third blast. This condition is safer enough for the stability of ramp and drive.

(5) The very purpose of creation of model-II is to increase the rate of advance of a drive by minimizing bolting operation requirement through identification of an appropriate number of blasts in a drive, from where the rock support system is exactly required and the same is concluded based on instrumentation results and validation.

1. Abdellah, W. R., Geotechnical Risk Assessment of Mine Haulage Drifts during the Life of a Mine Plan, University of McGill, Montreal, 2013, p. 352

2. Guntumadugu, D. R., Methodology for the Design of Dynamic Rock Supports in Burst Prone Ground, University of McGill, Montreal, 2013, p. 249.

3. Deere, D. U., Hendron, A. J., Patton, F. D. and Cording, E. J., Design of surface and near surface construction in rock. Failure and Breakage of Rock. In Proceedings of the 8th US Symposium Rock on Mechanics (ed. Fairhurst, C.), Society of Mining Engineering, American Institute of Mining, Metallurgical, and Petroleum Engineers, 1967, pp. 237-302.

4. Barton, N., Lien, R. and Lunde, J., Engineering classification of rock masses for the design of tunnel support. Rock Mech. Rock Eng., 1974, 6, 189-236.

5. Grimstad, E. and Barton, N., Updating of the Q-System for NMT In Proceedings of the International Symposium on Sprayed Concrete-Modern Use of Wet Mix Sprayed Concrete for Underground Support. (eds Kompen, C., Opsahl, S. L. and Berg, S. L.), Norwegian Concrete Association, 1993, pp. 46-66.

6. Dianmin, C., Design of Rock Bolting Systems for Underground Excavations, University of Wollongong, New South Wales, 1994, p. 275.

7. Murugamoorthy, C., Kho, C. M., Vaidya, B. G., Tang, S. K. and Subramanian, T., Behaviour of various support systems for deep excavations. In Station CAUM, RTS Conference, Changi Airport Underground MRT Station, Singapore, 2003.
8. Palmstrom, A. and Broch, E., Use and misuse of rock mass classification systems with particular reference to the Q-system. Tunnels Underground Space Technol., 2006, 21(6), 575-593.

9. Gharavi, M. and Shafiezadeh, N., A comparison of underground opening support design methods in jointed rock mass. Int. J. Eng. Trans. B: Applications, 2008, 21(3), 235-248.

10. Rafiee, R., Development rock behavior index around underground space using a rock engineering system. J. Geol. Min. Res., 2014, 6(4), 46-56; https://doi.org/10.5897/JGMR14.0205

11. Martin, C. D. and Maybee, W. G., The strength of hard-rock pillars. Int. J. Rock Mech. Mining Sci., 2000, 37, 1239-1246.

12. Hedley, D. G. F. and Grant, F., Stope and pillar design for Ellliot Lake Uranium Mines. Bull. Can. Inst. Mining Metal., 1977, 65, $37-44$.

13. Carter, T. G., Diederichs, M. S. and Carvalho, J. L., Application of modified Hoek-Brown transition relationships for assessing strength and post yield behaviour at both ends of the rock competence scale. In Proceedings of the 6th International Symposium on Ground Support in Mining and Civil Engineering Construction. (eds Stacey, T. R. and Malan, D. F.), SAIMM, Johannesburg, 2008, pp. 37-60.

14. Marinos, V., Geological behaviour of rock masses in underground excavations. Bull. Geol. Soc. Greece, 2010, 43(3), 1238-1247; doi:http://dx.doi.org/10.12681/bgsg.11300.

15. Singh, G. S. P. and Murthy, V. M. S. R., Applications of numerical modelling for strata control in mines. Geotech. Geol. Eng., 2010, 28(4), 513-524; https://doi.org/10.1007/s10706-010-9324-6

16. Yu, Z. S., Kulatilake, W. and Jiang, F., Effect of tunnel shape and support system on stability of a tunnel in a deep coal mine in China. Geotech. Geol. Eng., 2012, 30(2), 383-394; https://doi.org/ 10.1007/s10706-011-9475-0.

17. Rao, K. K., Choudhary, B. S. and Ghade, A., Critical analysis of process cycle by numerical modelling for faster development of drives in hard rock underground mines - a case study. Curr. Sci., 2020, 118, 1547-1556.

18. Kimmelmann, M. R., von Hyde, B. and Madgwick, R. J., The use of computer applications at BCL Limited in planning pillar extraction and design of mining layouts. In Proceedings of the ISRM Symposium Design and Performance of Underground Excavations (eds Brown, E. T. and Hudson, J. A.), British Geomechanics Society, London, 1984, pp. 53-63.

19. Krauland, N. and Soder, P. E., Determining pillar strength from pillar failure observations. Eng. Mining J., 1987, 8, 34-40.

20. Potvin, Y., Hudyama, M. R. and Miller, H. D. S., Design guidelines for open stope support. Can. Mining Metal. Bull., 1989, 82, 53-62.

21. Sjoberg, J., Failure modes and pillar behavior in the Zinkgruvan mine. In Proceedings of 33 US Rock Mechanics Symposium (eds Tillerson, J. A. and Wawersik, W. R.), Santa Fe, Rotterdam, AA Balkema, 1992, pp. 491-500.

22. Lunder, P. J. and Pakalnis, R. C., Determination of the smngth of hard-rock mine pillars. Bull. Can. Bst. Min. Metall., 1997, 90(1013), 51-55.

ACKNOWLEDGEMENTS. This work is supported by a Large mechanized Underground metal Mine of a Public sector company, situated in Kadapa district (India), which produces strategic mineral. The authors are grateful for the support of Mine Management.

Received 12 May 2020; accepted 8 March 2021

doi: $10.18520 / \mathrm{cs} / \mathrm{v} 120 / \mathrm{i} 11 / 1758-1767$ 